\title{
A model for simulating the deposition of water-lain sediments in dryland environments
}

\author{
Mark A. Bunch, Rae Mackay, John H. Tellam and Peter Turner \\ School of Geography, Earth and Environmental Sciences, University of Birmingham, Edgbaston, Birmingham. B15 2TT, UK \\ Email for corresponding author: mab061@bham.ac.uk
}

\begin{abstract}
A numerical process-imitating model, the Discrete Storm Event Sedimentation Simulator (DSESS), has been developed to represent the climatic and hydraulic conditions of drylands in modelling their geomorphological development and sedimentary facies distributions. The ultimate aim is to provide insights into the lateral variability of permeability in the Triassic Sandstone aquifers of the UK for the study of solute movement. DSESS employs discrete storm-flood automata, released across a cellular landscape, to model sediment transport: erosion, migration and deposition. Sediment classes with different grain sizes can be modelled. Empirical process-based equations are used to quantify the movement of the automata, their erosion potential, sediment-carrying capacity and interaction with the underlying sediments. The approach emphasises the sequence of dryland storm events and associated floods rather than their timing. Flood events are assumed to be discrete in time. Preliminary tests carried out with DSESS using simple systems and idealised initial conditions produce lithological and land surface features characteristic of dryland settings and indicate the potential of the model for large-scale, long-term modelling of sedimentary facies development. Markedly different results are observed across the range of tests carried out in response to the non-linear interactions between the different elements of the landscape and the floodwaters simulated with DSESS. Simulations show that sediment accumulations develop concave upward radial profiles, plano-convex cross-profiles and possess a general lateral grading of sediment with distance from source. The internal grain size architecture shows evidence of both persistent and rapidly changing flow conditions, with both lateral and longitudinal stepping of coarse bodies produced by 'scour and fill' events and random avulsions. Armoured layers form so that near-surface sediments have increased likelihood of preservation. Future developments will include representation of aeolian deposition, mass wasting and hyperconcentrated (debris) flows.
\end{abstract}

Keywords: avulsion, channel, deposition, drylands, erosion, gravel armouring, modelling, sheet-flood, transport capacity

\section{Introduction}

This paper describes a numerical model designed to simulate the deposition of water-lain dryland sediments. It is being developed as part of a research programme on groundwater solute movement through textured sedimentary aquifers. The principal aquifer of interest is the UK Sherwood Sandstone Group, a thick sequence of Triassic fluviatile and aeolian red-bed deposits (Benton et al., 2002). Prediction of solute movement requires knowledge of permeability distributions and, although a large data set is available on vertical variations in permeability (e.g. Allen et al., 1997), the data are widely spaced horizontally. Hence, knowledge of lateral variations in permeability is much less well quantified. One method for gaining an insight into the lateral variations of permeability in the sandstones is to use process-based modelling techniques to generate three-dimensional realisations of the aquifer lithology. If these can be validated against borehole core data, and if the effects of diagenesis can be represented, the modelled lithologies can be converted, ultimately, into permeabilities.

It appears that the dryland flash-flood type environment, responsible for so much of the deposition in Sherwood Sandstone times, has rarely been the subject of quantitative sedimentary process modelling and, hence, a new model has been developed. This paper is concerned only with the details of the approach used in the model and the results obtained during its preliminary testing: an application to the problem of groundwater solute movement has yet to be undertaken. 


\section{The nature of water-lain dryland sediments}

Drylands have been defined as regions that receive no more than $500 \mathrm{~mm}$ of precipitation a year (Grove, 1977): usually they are characterised as regions of irregular, infrequent, and locally intense rainfall. The majority of drylands occur in warm, arid regions centred on the tropics and sub-tropics (Tooth, 2000) and are often associated with high potential evapotranspiration. The highly variable and strongly localised precipitation encourages only sparse and uneven vegetation (Tooth, 2000). This leaves surface soils and unconsolidated sediments poorly protected and open to further fluvial action, aeolian deflation, crusting and the formation of desert pavements (Wright et al., 1991). Generally, erosion rates are high, with surface hydraulic processes able to erode and transport a large quantity of sediment during a single flood event (Reid and Frostick, 1987).

Dryland precipitation characteristics mean that short-term rainfall depths often exceed the long-term annual average (Tooth, 2000). As a result, dryland fluvial systems are primarily ephemeral and often dry for extended periods: Knighton and Nanson (1997) suggest that 100 and 1000 year flood flows in drylands can be, respectively, almost an order of magnitude, and up to two orders of magnitude, greater than long-term annual average flows. Erosion and deposition in these systems are, thus, largely event-based phenomena. Dryland soil infiltration rates are low and spatially variable (Tooth, 2000). Runoff occurs even during limited duration rainfall events and is dominated by Hortonian overland flow, with various degrees of channelisation, from purely channel flow to entirely sheet flood. The drainage networks are often poorly connected because of the localisation of flooding and infiltration and erosion upstream will give way to deposition downstream (Tooth, 2000).

Although limited, the infiltration losses in dryland river systems can be enough to prevent flows from travelling the full length of the channel (Tooth, 2000). Storm events are unlikely to wet the entire drainage network and successive localised storms may wet different parts of the network (Reid and Frostick, 1987). The observation in humid fluvial networks that trunk channel flow is maintained by an accumulation of tributary flow along its reach (Blair and McPherson, 1994) does not hold, necessarily, for dryland river systems. The flashiness of flood hydrographs and the susceptibility of surface sediments to entrainment mean that dryland flows act as non-uniform, non-steady, discontinuous agents of mass sediment transfer. A dryland storm can be thought of as giving rise to a non-synchronised, autogenic 'scour and fill' event, controlled more by local flow conditions than by trends in allogenic stresses (Salter, 1993).

\section{Previous fluvial sedimentation models}

Many fluvial sedimentation models have been developed to represent river systems in temperate climates (e.g. Tucker et al., 2001; Willgoose et al., $1991 \mathrm{a}$,b; Howard et al., 1994; Willgoose, 1994; Tucker and Slingerland, 1997; Smith et al., 1997a,b; Tucker and Bras, 1998; Davy and Crave, 2000; Hardy et al., 2000; Crave and Davy, 2001; Veldkamp and Tebbens, 2001). However, this work is of limited relevance to dryland water-lain deposition: as discussed above, the processes in the two environments are very different. Most existing models represent fluvial processes by assuming continuity across the model domain. Such models are inappropriate to simulate the hydraulic processes in dryland environments where the events that govern landscape development are discontinuous in space and time. Accordingly, this paper presents the formulation of a new numerical process model for simulating the redistribution of multi-grain size clastic sediment over geological timescales in dryland environments. The model has been named the Discrete Storm Event Sedimentation Simulator (DSESS).

\section{Model design}

\section{OVERVIEW}

The modelling scheme is based on cellular automata (Fig. 1). The area to be modelled is represented by a grid of cells, each cell containing a column of sediment above a userspecified bedrock elevation, the column rising to a height representing initial ground surface. The sediment has a grain size distribution which can vary with depth. Storm water is simulated by adding automata, or 'precipitons' (Crave and Davy, 2001), to cells. Each precipiton has a defined initial volume of water, expressed as a depth. The extent of the area affected by a storm is represented by adding precipitons in appropriate grid cells. For precipitons entering the model area across a lateral boundary, a sediment load for each grain size can also be defined. Storm events are assumed to be independent and do not overlap in time. The precipitons move across the landscape, one cell at a time, in a direction determined by the direction of the ground surface gradient. As the precipiton moves, it erodes or deposits sediment depending on its flow rate, sediment carrying capacity and current sediment load. Thus, the ground surface morphology becomes modified, which in turn affects flow and, thence, subsequent sediment transport. Time is not represented 


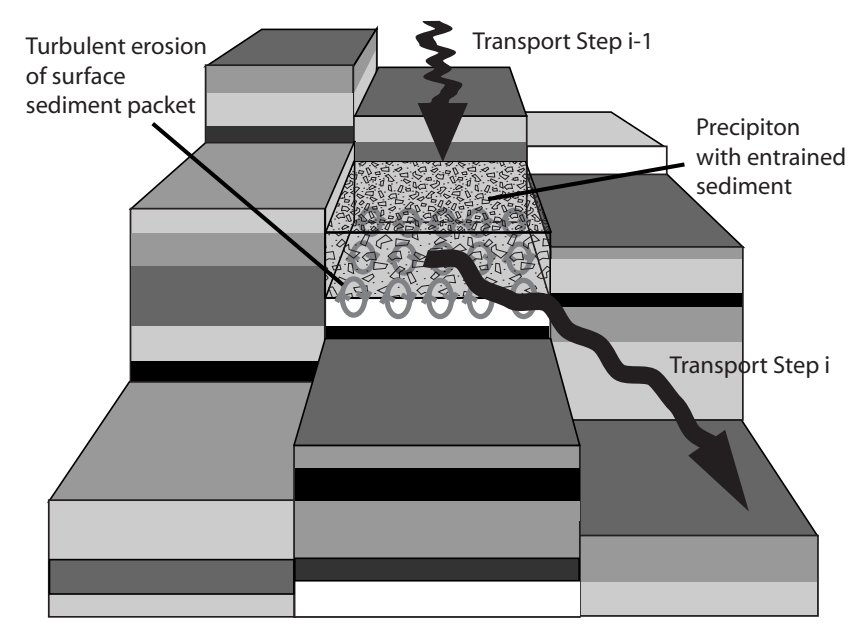

Fig. 1. Illustration of the sediment columns and the stochastic movement of a precipiton over two transport steps. The shading indicates mean grain size.

explicitly and each movement occurs in what will be described as a 'transport step' rather than a time step. Because time is not represented directly, account is taken of the relative timings of the arrivals of different precipitons at the same cell. The movement of a precipiton will cease eventually and it will, then, be removed from the model. The movement of a precipiton will cease for one of the following reasons: the boundary of the model domain is reached; the precipiton reaches a topographic low; or infiltration losses from the water in the precipiton reduce flows to zero. Once all the precipitons have been removed, another set can be added: these will represent the next storm event.

\section{DETAILS OF THE MODEL CALCULATIONS}

The grid: Each cell of the model grid is considered to contain a vertical series of sediment 'packets' as indicated by the layered grey shading in Fig. 1. These sediment packets lie above an un-erodible bedrock base, the elevation of which can be specified separately at each cell. For each packet, the following information is recorded or can be calculated: thickness, elevation of base, volumetric grain size distribution, porosity, bedform, Mannings' roughness coefficient, palaeo-flow direction, depositional flow regime and time of deposition. In the current model, the cell size has been taken as 50 by $50 \mathrm{~m}$. A smaller size would be preferable, as river channel widths in the environments modelled are more likely to be in the range 10 to $25 \mathrm{~m}$ (Tooth, 2000) but, for evaluation purposes, $50 \mathrm{~m}$ has the advantage of a faster processing speed.
Precipitons: For each precipiton, the following information is recorded or can be calculated: flow depth, volume, volumetric grain size distribution, fluid (i.e. sediment slurry) density, fluid viscosity, boundary shear stress, Reynolds' Number, and Froude Number. The current model has three grain size classes, the definitions of which are user-specified. A maximum sediment load is set: in the current model, this is $20 \%$ (volume/volume) to reflect the threshold for hyper-concentrated flows (Abrahams et al., 2001). Above this threshold, especially if there is a high proportion of clay- and silt-sized sediment, the viscosity of a dynamic fluid suspension increases markedly, allowing much higher concentrations of sediment to be carried (Franzi, 2002) and debris flow occurs. Hence DSESS does not currently represent conditions well on steep slopes where such debris flows become important (Blair and McPherson, 1994; Edwards et al., 1997; Collinson, 1996; Blair, 1999c). Future versions of DSESS will include representations of debris flow dynamics, using the results of Imran et al. (2001), D'Ambrosio et al. (2002), Drago (2002) and, particularly, Franzi (2002).

Determination of the direction of flow: The direction of movement of a precipiton in a transport step is determined from the ground level gradients in its vicinity. Gradients are calculated from the present cell location towards all eight adjacent cells. Next, all up-hill gradient directions are discarded. A weighting is then given to each of the remaining directions in proportion to the magnitude of the gradient. Finally, the direction of movement is chosen stochastically using these weightings. If there are several possible path directions and the largest two gradient weights combine to exceed $80 \%$ of the total of gradient weights but yet differ by less than $10 \%$, the precipiton is split into two, each new precipiton moving in the direction of the steepest two slopes: mass balance is maintained, the split being proportional to the gradients. The resulting distributary style of channelling is a feature of dryland fan settings and allows the possibility of representing flow 'unconfinement' (Kelly and Olsen, 1993; Blair and McPherson, 1994). This 'flow splitting' also reduces the dependence of the morphological development on the paths taken by the earliest precipitons. If all gradients are directed upwards, the precipiton is trapped and is assumed to lose all its water by infiltration. However, enough sediment may be deposited by a precipiton in a topographic low to raise the ground surface elevation sufficiently so that onwards flow can occur during the next transport step. To account for this, the scheme illustrated in Fig. 2 has been used (see Davy and Crave (2000); Crave and Davy (2001); and Clevis et al. (2003)). 


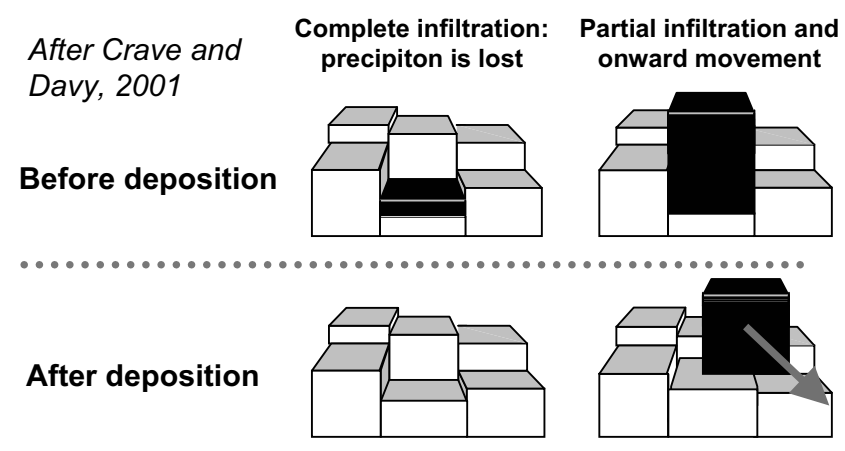

Fig. 2. Deposition of sediments in local land surface minima.

Calculation of flow rate: Flow rate is calculated assuming steady-state continuous one dimensional flow, using Manning's equation:

$$
U=\frac{1}{n} R^{\frac{2}{3}} S^{\frac{1}{2}}
$$

where $U$ is the average flow velocity[$\left[\mathrm{LT}^{-1}\right] ; n$ is the Manning roughness coefficient $\left[\mathrm{TL}^{-1 / 3}\right] ; R$ is the hydraulic radius [L]; and $S$ is the channel bed gradient [-]. $n$ is estimated from the grain size distribution using Graf and Altinakar (1998):

$$
n=\frac{{ }^{*} D_{50}^{1 / 6}}{21.1}
$$

where ${ }^{*} D_{50}$ is the sediment grain diameter in mm such that $50 \%$ of the sediments present by volume have smaller diameters. The hydraulic radius is taken to be equal to the flow depth because of the large width to depth ratio imposed by the choice of a $50 \mathrm{~m}$ cell size (Graf and Altinakar, 1998). Flow depth is calculated from the dimensions of the cell and the volume of water.

The volume of water is reduced at the end of each transport step by an amount representing infiltration. The infiltration rate is assumed to be dependent on how long the surface sediment packet has been exposed. Surface sediment is classified as either old or new. Old sediment is that which has remained unmoved for a user-specified number of storm events and is assumed, therefore, to be compacted. New sediment has been deposited more recently. Infiltration losses are assumed to be greater in the new sediment: in the current version of the model, the rates are set at $110 \mathrm{~mm} \mathrm{~h}^{-1}$ and $420 \mathrm{~mm} \mathrm{~h}^{-1}$ respectively, in accordance with modelling work on Hortonian flow in an arid catchment in Israel by Lange et al. (1999). No account is taken of the thickness or grain size of the uppermost sediment packet, or of water table depth. The infiltration volumes are calculated using the rates and the time taken for the precipiton to cross the active cell. In combination with flow splitting, infiltration helps to simulate the occurrence of 'flood outs' (Tooth, 1999). These occur where channels become less well defined in the lower reaches of an alluvial fan and flow spreads, with consequent rapid diminishing of flow rate and, therefore, also of transport capacity. Rapid loss of sediment transporting capacity has also been suggested as the reason behind the distinctive gradients and morphology of the margins of alluvial fans (Kelly and Olsen, 1993; Blair and McPherson, 1994).

Calculation of sediment transport: Sediment will move if the dimensionless flow shear stress is greater than the Shield's criterion value and if the fluid's transporting capacity is not already satisfied (e.g. Graf and Altinakar, 1998).

To assess the former condition, the flow shear stress is calculated using (Graf and Altinakar, 1998; Paola, 2000):

$$
\tau_{*}=\frac{\gamma R S}{\left(\gamma_{s}-\gamma\right) D_{50}}=\frac{R S}{\Delta D_{50}}
$$

where $\tau_{*}$ is the dimensionless flow shear stress [-]; $\gamma$ is the unit weight of the mixed-phase fluid $\left[\mathrm{ML}^{-2} \mathrm{~T}^{-2}\right] ; \gamma_{s}$ is the unit weight of sediment $\left[\mathrm{ML}^{-2} \mathrm{~T}^{-2}\right] ; \Delta=\left(\gamma_{\mathrm{s}}-\gamma\right) / \gamma, D_{50}$ is the sediment grain diameter such that $50 \%$ of the sediments present by volume have smaller diameters [L]. Once calculated, the value of $\tau_{*}$ can be compared with the appropriate Shields' criterion.

To estimate the sediment-transporting capacity for sub hyper-concentrated flow, the following relationship was used (Abrahams et al., 2001):

$$
\phi=a \tau_{*}^{\frac{3}{2}}\left(1-\frac{\tau_{*_{c}}}{\tau_{*}}\right)^{3.4}\left(\frac{U}{U_{f}}\right)^{c}\left(\frac{w_{i}}{U_{f}}\right)^{-\frac{1}{2}}
$$

where $\phi$ is the dimensionless sediment transport capacity $[-] ; \tau_{*_{c}}$ is the critical dimensionless shear stress for entrainment of the $\mathrm{D}_{50}$ grain size class, i.e. the Shields' criterion [-]; $a$ and $c$ are channel form roughness parameters that represent obstruction of flow by channel-bound obstacles; $U_{f}$ is the 'friction' or 'shear' velocity at the channel bed (Graf and Altinakar, 1998; Abrahams et al., 2001); and $w_{i}$ is the settling velocity of sediment particles of the appropriate $\mathrm{D}_{50}$ size. Values for the roughness parameters, $U_{f}$ and $w_{i}$ are estimated using the approaches described below.

The channel form roughness parameters $a$ and $c$ are estimated by (Abrahams et al., 2001):

$$
\log a=-0.42\left(\frac{C_{r}}{D_{r}}\right)^{0.2}
$$

and

$$
c=1+0.42\left(\frac{C_{r}}{D_{r}}\right)^{0.2}
$$


where $C_{r}$ is the area of roughness elements per unit area [-] and $D_{r}$ is the average diameter of roughness elements in $\mathrm{m}$. Roughness elements can be used to take into account the presence of vegetation or large obstructions.

The 'friction' velocity at the channel bed is given by (e.g. Abrahams et al., 2001):

$$
U_{f}=\sqrt{(g R S)}
$$

where $g$ is the acceleration due to gravity $\left[\mathrm{LT}^{-2}\right]$. The settling velocity of the particles $\left(w_{i},\left[\mathrm{LT}^{-1}\right]\right)$ is estimated by Stoke's Law in the current model, though other expressions could be used:

$$
w_{i}=\sqrt{\left(\Delta D_{50}\right)}
$$

Once the dimensionless sediment transporting capacity $(\phi)$ has been calculated, it is converted to a sediment transport rate per unit width $\left(q_{s,}\left[\mathrm{~L}^{2} \mathrm{~T}^{-1}\right]\right)$ using:

$$
q_{s}=\phi\left(\Delta D_{50}{ }^{3}\right)^{\frac{1}{2}}
$$

In the current model, only one value of this sediment transporting capacity is calculated and is applied to all the grain sizes.

Finally, the maximum volume of sediment that the flow can transport is calculated by multiplying $q_{s}$ by the time taken for a precipiton to cross the present grid cell. If this value is greater than the volume actually being transported, then erosion can occur: if the capacity is less than is being transported, deposition will occur. If erosion is predicted, grain sizes are entrained as long as the shear stress is greater than the respective Shields' criterion. If the shear stress is not large enough to transport all the particles, finer grains are removed leaving a coarser deposit. To prevent this winnowing process from penetrating too deeply into the sediment profile, it is only permitted to occur in the uppermost sediment packet, irrespective of whether there is excess transporting capacity after all the fine sediment has been removed from this packet. The resulting, winnowed, deposit acts as an armoured layer which may protect underlying sediment packets from erosion associated with subsequent precipitons. Such armouring is seen in real systems (e.g. Graf and Altinakar, 1998; Collinson, 1996). If deposition is predicted, sediment is removed from the fluid phase in order of decreasing grain size until the volume entrained is the same as the predicted capacity (Kolterman and Gorelick, 1992).

No account is taken of chemical precipitates formed between flood events (Wright et al., 1991; Collinson, 1996; Kocurek, 1996). Such features may be important in affecting the developing channel networks (Tooth, 2000). It is also assumed that there are no effects due to flocculation (e.g. Collinson, 1996). No direct account is taken of vegetation, or of slope instability. Finally, no account is taken of aeolian redistribution of sediments.

Interaction of precipitons: The use of the automaton approach means that precipitons are moved one cell in each transport step irrespective of their velocities. This will lead to inconsistencies when different precipitons pass across the same cells at some stage in their migration - the order in which they cross the cell may well not be correct and, because each time a precipiton passes through a cell it can change the properties of the surface sediment, inappropriate predictions may be made. To reduce the effects of this problem, the precipitons are moved in order of decreasing velocity: the calculations for the current transport step are undertaken, starting with the precipitons which had the highest velocity in the previous transport step. This means that, at least within a transport step, the fastest precipitons will get out of the way of some of the slower precipitons, and catch up with others. A better approach would be to track the paths and timings, but this would be significantly more expensive computationally, and has not yet been incorporated in the model.

When simulating a storm, it is often necessary to load many precipitons at one cell. These precipitons are not merged as this would give unrealistically deep and therefore rapid flows. Instead, each precipiton, with a defined water depth, is tracked in turn from the common introduction cell to the next cell downstream: because earlier precipitons may have modified the sediment pile, it is possible that the precipitons may not all move onto the same downstream cell, and as more transport steps are calculated, the precipitons may disperse. If by the end of a subsequent transport step two precipitons happen to have landed on the same cell from different directions, they are merged.

Fate of precipitons: Precipitons will be terminated by reaching the edges of the modelled area, by reaching a topographic low, or by infiltration removing all the water. The latter two mechanisms have already been discussed so that further explanation is required only for the first.

A precipiton is moved across a boundary by assuming that the ground surface gradient traversed in the previous transport step is maintained across the boundary. This can lead to positive feedback and generate unrealistic erosion at the edges of the model. Hence, boundaries should be placed distant from zones of interest within the model area. Once a precipiton is lost from the system, its sediment attributes are removed from circulation and accounted for 
in a calculation of the system mass balance.

\section{Verification of the model}

\section{TEST SIMULATIONS}

Test simulations have been run to determine the extent to which DSESS will reproduce the style of the spatial features observed in dryland-deposited formations. The results of these simulations are being examined visually and compared with features observed in actual geological systems as part of an ongoing verification process. This testing has so far shown that the code is functioning effectively and is fit for the purpose of generating alternative realisations of geological media. A more detailed validation of a DSESSbased model will be undertaken in future: this will involve a simulation of a section of the Permo-Triassic sandstones in south-west England.

Two simulation sets investigating small-scale erosion and deposition features are described here to illustrate the verification process and to demonstrate the utility of the code for generating models of dryland-derived geological formations. The test sets are based on idealised geological settings for the initial land surface and consider a square region of $2.1 \mathrm{~km}^{2}$ (Fig. 3). Set A considers a uniformly dipping land surface with different angles of dip, while set B considers a uniform step in the middle of a land surface with a vertical offset of $88 \mathrm{~m}$. The land on either side of the offset is very gently sloping $(<0.002)$ with a dip perpendicular to the step: the step extends across the full width of the land surface. A horizontal grid spacing of $50 \times 50 \mathrm{~m}$ has been used for all simulations. In all cases, the initial geological profile comprises uniformly mixed sediments with three grain sizes in equal proportions: $0.25 \mathrm{~mm}$ (fine/medium sand), $1.0 \mathrm{~mm}$ (coarse sand) and $4.00 \mathrm{~mm}$ (gravel). The sediment piles at the start of the simulations are sufficiently deep that erosion never penetrates to unerodible bedrock.

Ten thousand flood events, each composed of 29 precipitons, each of volume $2500 \mathrm{~m}^{3}$, have been generated for each simulation. The precipitons enter the model area at a single cell at the middle of the boundary face with the highest land elevation (Fig. 3). Each flood event discharges a maximum of 72.5 thousand cubic metres onto the model area and the flow depth at the inlet (i.e. the water depth associated with each precipiton at the time of introduction) is taken to be $1 \mathrm{~m}$. Sediment loads in the flood water at the point it enters the modelled area are set as either zero or $5 \%$ by volume with the same grain sizes and proportions as in the initial geological profile.

Table 1 summarises the two sets of simulations that have

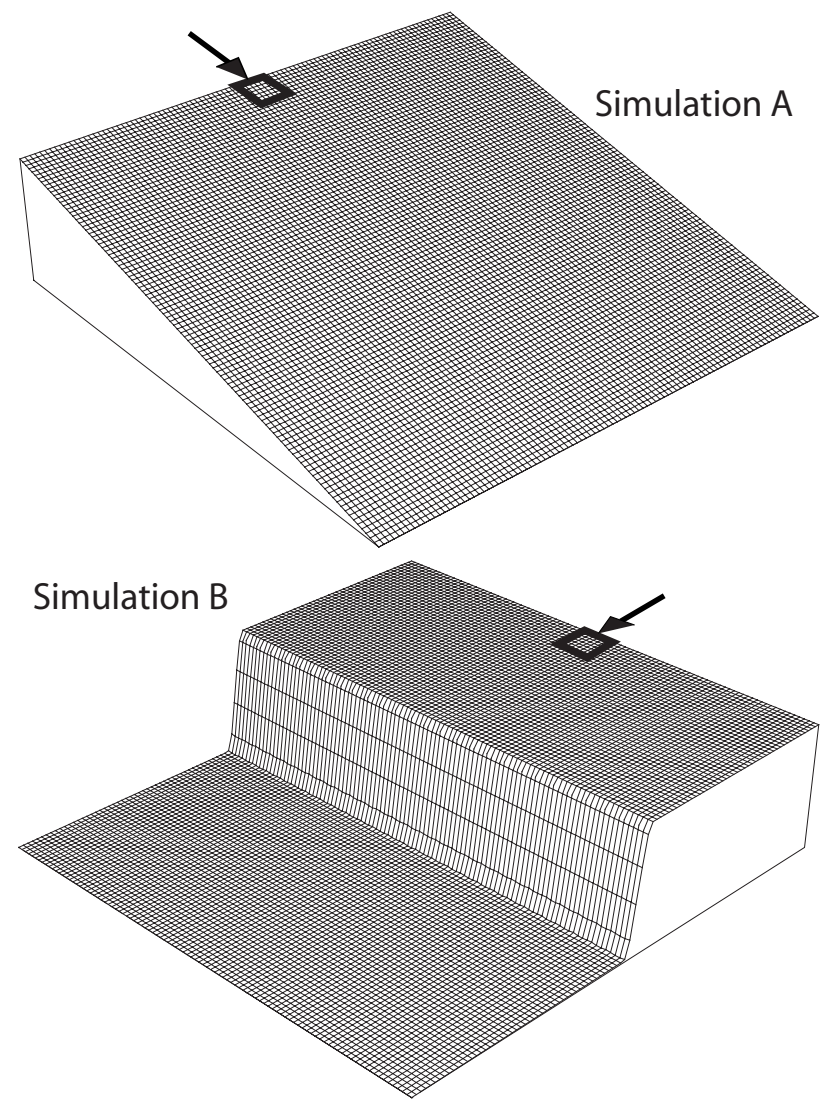

Fig. 3. Initial land surface shape for simulations $A$ and $B$. The square indicates the precipiton source position. The arrow indicates the direction of the local gradient at the source position.

been carried out. Table 2 lists the constants that have been used in the models.

\section{SIMULATION SET A}

The initial slope $\left(0.4^{\circ}\right)$ for simulations A1.1 and A1.2 is around the maximum for a lowland river (Blair and McPherson, 1994). With no entrained sediment (A1.1), a stable channel is formed running essentially in the line of the initial slope's steepest descent but exhibiting some sinuosity in the path of the channel (Fig. 4-A1.1). The orientation of the channel reflects early time flow directions. The channel is shallow, at about $1.5 \mathrm{~m}$, and the deposits in and near the channel are coarser than in the surrounding area. The limited erosion appears to be the result of armouring of the bed and the low erosion potential of the low sediment concentration, low velocity flood waters.

With entrained sediment in the storm water entering the model area (A1.2), an alluvial fan develops (Fig. 4-A1.2). The mean slope of the fan is about $1.5^{\circ}$, which is close to the lower limit for dryland fan slopes suggested by Blair and McPherson (1994). This result suggests that small 
Mark A. Bunch, Rae Mackay, John H. Tellam and Peter Turner

Table 1. Summary of the simulations and their primary characteristics

\begin{tabular}{lcclc}
\hline Simulation & Initial land slope & Initial land step & $\begin{array}{l}\text { Time dependent } \\
\text { flood distribution }\end{array}$ & Flood sediments \\
\hline A1.1 & $0.4^{\circ}$ & $0 \mathrm{~m}$ & Uniform & 0 \\
$\mathrm{~A} 1.2$ & $0.4^{\circ}$ & $0 \mathrm{~m}$ & Uniform & $5 \%$ \\
$\mathrm{~A} 2.1$ & $25^{\circ}$ & $0 \mathrm{~m}$ & Uniform & 0 \\
$\mathrm{~A} 2.2$ & $25^{\circ}$ & $0 \mathrm{~m}$ & Uniform & $5 \%$ \\
$\mathrm{~A} 3$ & $30^{\circ}$ & $0 \mathrm{~m}$ & Uniform & 0 \\
& & & & \\
$\mathrm{~B} 1$ & $0^{\circ}$ & $88 \mathrm{~m}$ & Uniform & $5 \%$ \\
$\mathrm{~B} 2$ & $0^{\circ}$ & $88 \mathrm{~m}$ & Uniform & $\mathbf{5 \%}$ \\
$\mathrm{B} 3$ & $0^{\circ}$ & $88 \mathrm{~m}$ & Linearly decreasing & \\
\hline
\end{tabular}

Table 2. Constants used for the simulations

\begin{tabular}{|c|c|}
\hline Property Constants & Value \\
\hline Water Density $\left(\rho_{\mathrm{w}}\right)$ & $1000 \mathrm{~kg} \mathrm{~m}^{-3}$ \\
\hline Grain Density $\left(\rho_{s}\right)$ & $2650 \mathrm{~kg} \mathrm{~m}^{-3}$ \\
\hline Gravitational acceleration $(\mathrm{g})$ & $9.81 \mathrm{~ms}^{-2}$ \\
\hline Concentration of roughness elements $\left(\mathrm{C}_{\mathrm{r}}\right)$ & $0.05 \mathrm{~m}^{-2} \mathrm{~m}^{-2}$ \\
\hline Average diameter of roughness elements $\left(D_{r}\right)$ & $1 \mathrm{~m}$ \\
\hline $\begin{array}{l}\text { Sandstone consolidation factor } \\
\quad \text { (Allen and Allen, 1990, } \\
\text { after Sclater and Christie, 1980) }\end{array}$ & $0.27 \mathrm{~km}^{-1}$ \\
\hline $\begin{array}{l}\text { Porosity of newly deposited sands } \\
\text { (Allen and Allen, 1990) }\end{array}$ & $49 \%$ \\
\hline $\begin{array}{l}\text { Angle of Repose of sandy sediments } \\
\text { (Abrahams et al., 2001) }\end{array}$ & $32^{\circ}$ \\
\hline $\begin{array}{l}\text { Dynamic viscosity of water at } 25^{\circ} \mathrm{C} \\
\text { (Weast, 1981) }\end{array}$ & $8.90 \times 10^{-4} \mathrm{Pas}$ \\
\hline $\begin{array}{l}\text { Maximum sediment capacity per storm precipiton } \\
\text { (Abrahams et al., 2001) }\end{array}$ & $20 \%$ \\
\hline $\begin{array}{l}\text { Infiltration rate of fresh sediments } \\
\text { (Lange et al., 1999) }\end{array}$ & $420 \mathrm{~mm} \mathrm{~h}^{-1}$ \\
\hline $\begin{array}{l}\text { Infiltration rate of old sediments } \\
\text { (Lange et al., 1999) }\end{array}$ & $110 \mathrm{~mm} \mathrm{~h}^{-1}$ \\
\hline $\begin{array}{l}\text { Shield's critical shear stress criterion } \\
\text { (Graf and Altinakar, 1998) }\end{array}$ & 0.045 \\
\hline $\begin{array}{l}\text { Modified bedrock erosion rate } \\
\text { (adapted from Clevis et al., 2003) }\end{array}$ & 100 years $^{-2 / 3}$ \\
\hline
\end{tabular}

differences in the sediment amount can result in major differences in the surface morphology. The tendency for the sediment to be deposited directly on entry to the model area reflects the imbalance between the sediment supply and the initial land surface slope. The radial fan forms around the inlet and sediment is spread across most of the model domain. Mean grain sizes reduce with distance from the inlet and are much greater than for simulation A1.1 over the model region. Essentially, the fine fractions are being discharged at a greater rate from the model area than the coarse fractions in this case, whereas the fine and coarse fractions are more equally eroded in simulation A1.1.

For the second pair of simulations (A2.1 and A2.2), the land slope is $25^{\circ}$, close to the maximum for an alluvial fan (Blair and McPherson, 1994). For the simulation with no entrained sediment in the storm water entering the model area (A2.1), erosion is dominant and the land surface is lowered in some areas by tens of metres over the simulation period (Fig. 4-A2.1). Erosion takes place across a broad front rather than being channelled and lack of sorting of grain sizes is also observed for this simulation (Fig. 5-A2.1). This contrasts with simulations A1.1 and A1.2 where erosion is only of the order of a metre and is highly localised, i.e. channels form (these channels rapidly infill in A1.2 causing frequent avulsion). The reason for this appears to be connected with the gradient weighting rule used in the stochastic calculation of the direction taken by a precipiton. For shallow slopes, minor amounts of erosion can increase ground surface gradients locally, thus significantly changing the weightings for the calculation of the direction of flow in the next transport step. As the weightings will be changed in such a way as to favour the direction of increased gradient, more flow occurs in this direction, and this in turn leads to more erosion, and hence a positive feedback becomes established. For higher angle slopes, even though erosion capacities are greater, more material has to be eroded before the weightings are changed significantly. Thus, a feedback loop is more difficult to establish, and the erosion will be approximately evenly distributed, the pattern closer to that expected from weightings based on a uniformly dipping slope.

Simulation A2.2, however, shows the formation of a 


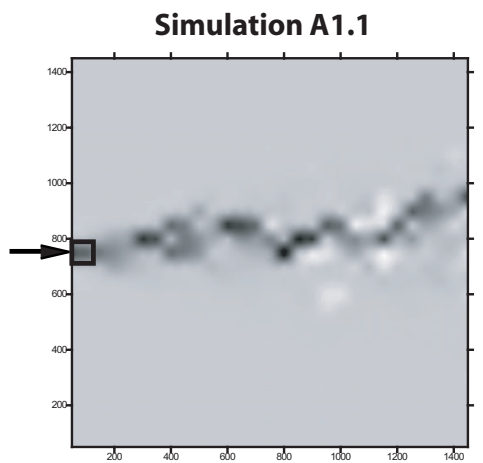

Simulation A1.2

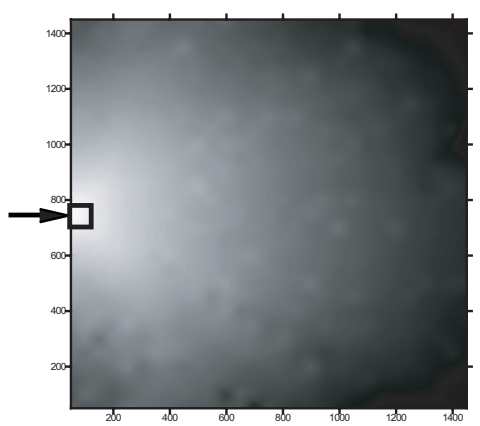

Simulation A2.1

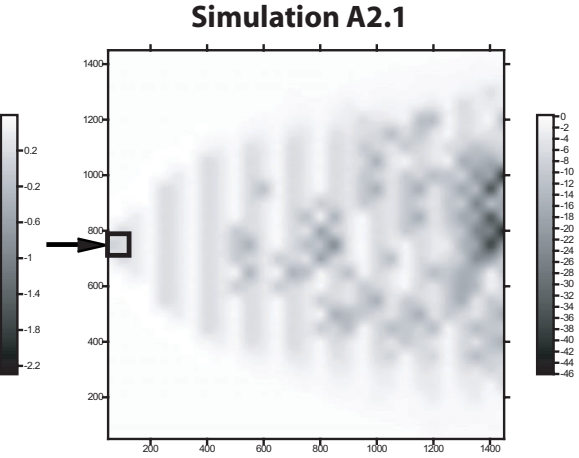

Simulation A2.2

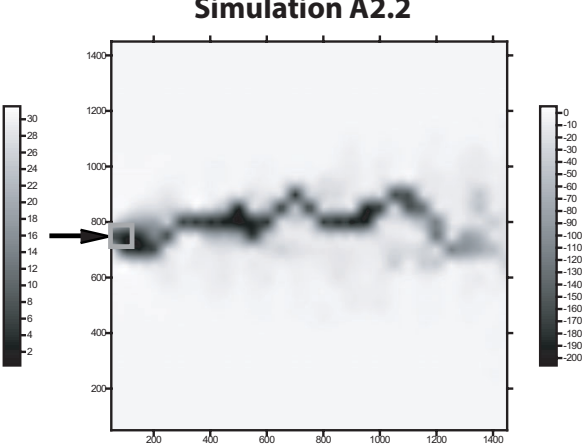

Simulation A3

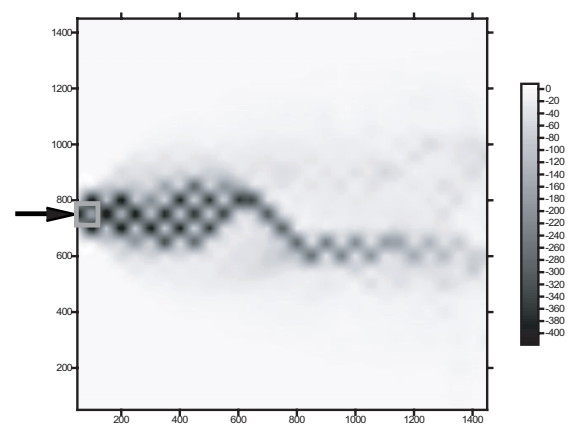

Legend

$\rightarrow \square \begin{aligned} & \text { Precipiton source } \\ & \text { position }\end{aligned}$

Scale bars are given in metres relative to the original surface

Fig. 4. Plan view of elevation change over the model domain at the end of simulations A1.1 to A3.
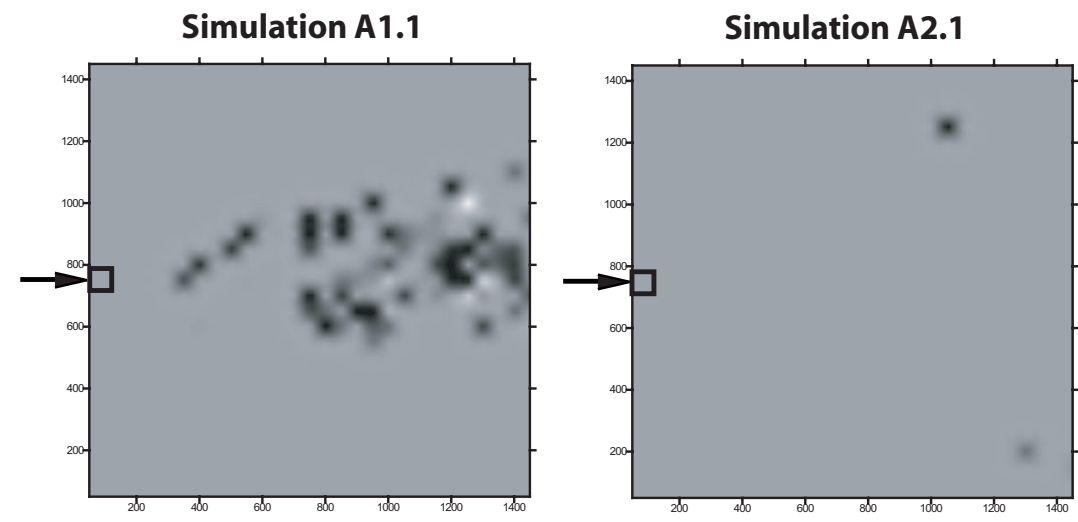

Simulation A1.2

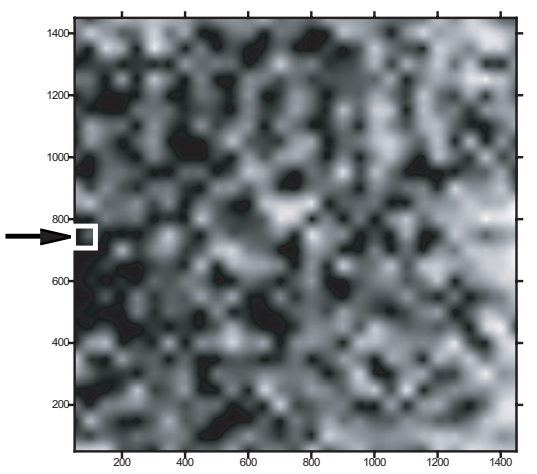

Simulation A2.2

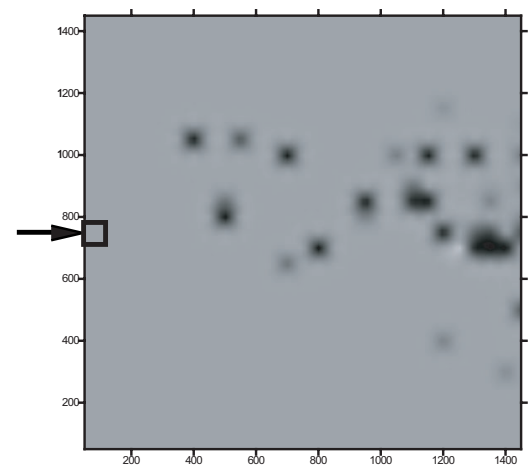

Simulation A3

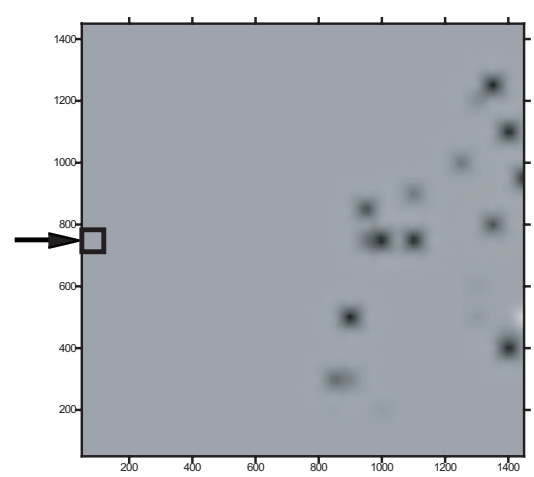

Legend

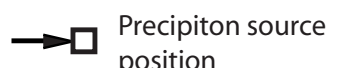
position

Scale bar

Mean surface sediment grain size in millimetres

Fig. 5. Plan view of surface mean grain size distribution at the end of simulations A1.1 to A3. 
dominant channel in the upper portion of the slope. This appears to be because the greater erosive power brought about by the presence of the entrained sediment is enough to establish the feedback loops discussed above. System A2.1 was apparently very close to the boundary between channel excavation and evenly-distributed erosion behaviour and, therefore, very sensitive to the small increase in erosion capacity resulting from the increase in entrained sediment content: presumably the same result would have been obtained if slope angle or depth of water had increased instead of entrained sediment (see A3 below). Although this result may be an artefact of the weightings chosen, channelling is expected for a single source on a relatively steep slope (Blair, 1999b; Tooth, 2000). The depth of the channel produced in simulation A2.2 is rather unrealistic as slope stabilities would suggest that the side slopes of the channel ought to collapse. This mechanism of channel bank failure is not present in the current DSESS model and should be added before the proposed detailed validation is carried out. Armouring of the channel does not appear to take place and this is almost certainly the result of the combined choice of a maximum grain size of $4 \mathrm{~mm}$ and the steep slope.

For simulation A3, the very steep slope of $30^{\circ}$ was adopted, significantly greater than the maximum slope expected for an alluvial fan. No entrained sediment was present in the water. A channel was formed rapidly with very high incision rates. Again this contrasts nicely with the result from simulation A2.1, and confirms the sensitivity of the system to the balance between the erosion power and the amount of sediment that needs to be excavated before flow directions are affected significantly. The broad incision, spanning many grid cell widths, indicates that the channel does not form immediately but develops over time. The width of the erosion front downstream indicates that the channel incision was less well-defined here - the channel did not retain most of the flow. This suggests that the erosion rates downstream were limited, probably because the sedimentcarrying capacity had largely been attained further upstream - i.e. the precipitons are nearly or completely 'full' of sediment downstream. The erosion depths are unrealistic for the same structural stability reasons identified for simulation A2.2.

\section{SIMULATION SET B}

These simulations were developed to represent, in idealised form, the effects on sedimentation of the presence of a sharp change in topographic elevation caused, for example, by differential uplift/downthrow between two adjacent rock masses. The difference between this case and the preceding case arises from the link between the erosion rates of the upland region and the sediment deposition in the lowland region. This is most clearly illustrated for simulations B1 and B2 (Fig. 6). For simulation B1, the entrained sediment is zero and a simple channel is formed on the upland region as for case A1.1. This leads to local erosion at the topographic step and production of a small fan as a result of deposition of the sediments on the lowland region. The amount of erosion and deposition is relatively small. Fence diagrams showing the internal grain size structure of this fan, and those of the other Set B fan simulations, are shown in Fig. 7.

In the case of simulation B2 ( $5 \%$ by volume entrained sediment), sediments are initially deposited on the upland region as predicted by the results of simulation A1.2. However in this case, the result leads to spreading of the flows on the upland region and, as a direct consequence, a broad area of erosion at the step. The amount of sediment in the resulting alluvial fan on the lowland area is much

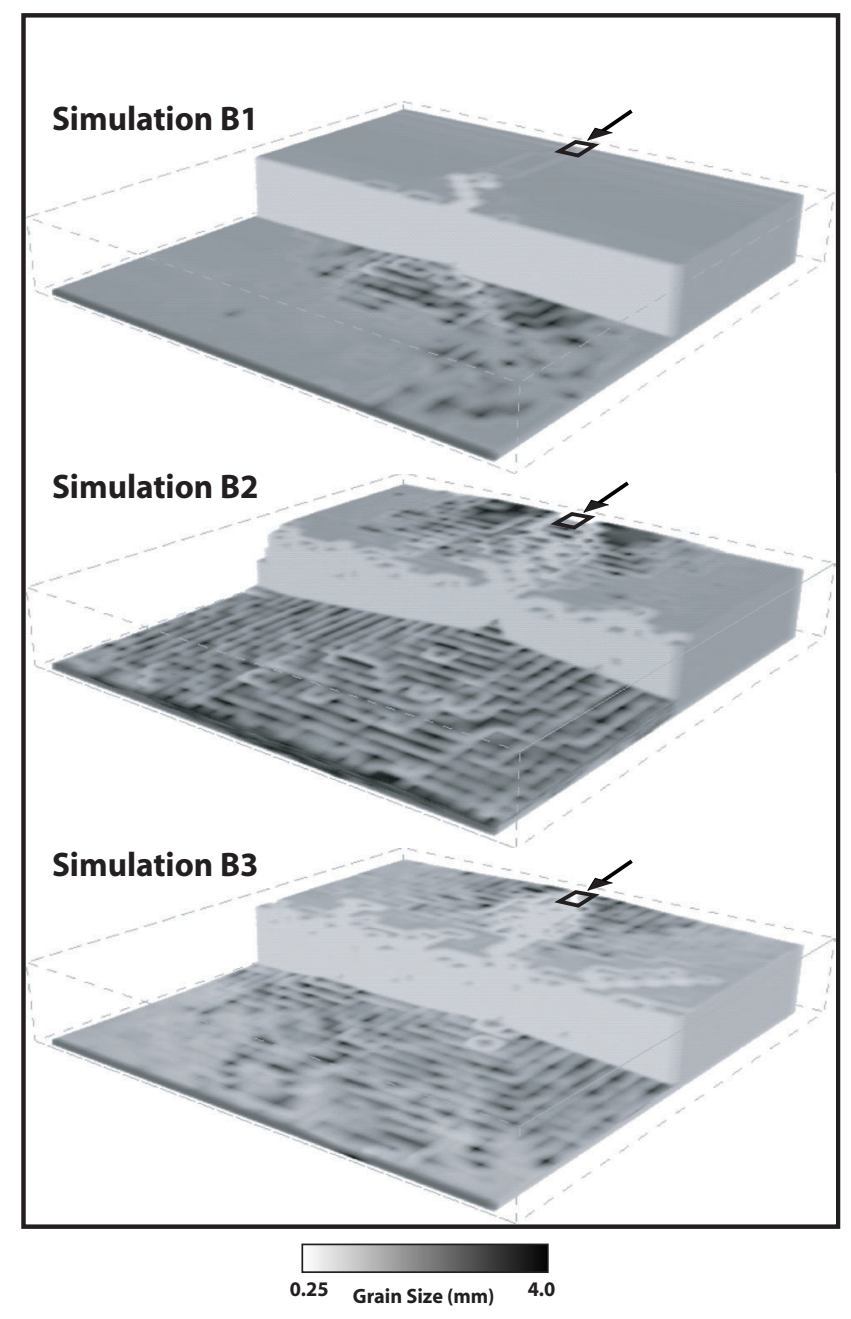

Fig. 6. Surface grain size distribution at the end of simulations B1, $B 2$ and $B 3$. 


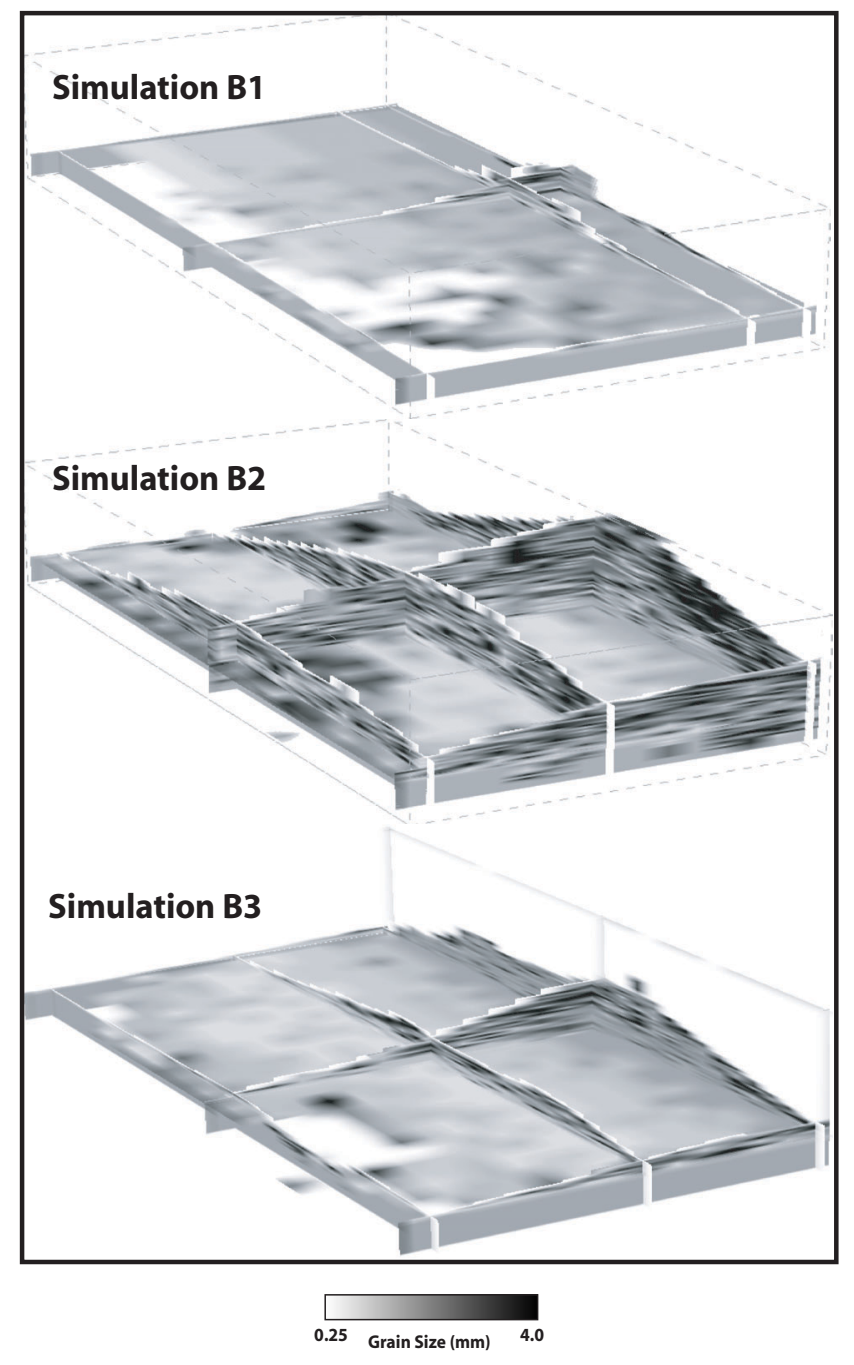

Fig. 7. Internal grain size distribution of reworked and deposited sediments of the lower fan at the end of simulations B1, B2 and B3.

greater due both to the increase in the available sediments and to the increase in the erosive power of the sedimententrained flows. Flow orientations change regularly and the pattern of sediment grain sizes appears to reflect interferences between local armouring and depositional processes (Fig. 7-B2).

Simulation B3 provides a variant on the defined flood event regime used for the previous simulations. In this case, the volume of water involved in each storm event decreases with subsequent events linearly from a maximum at storm 1 to zero at storm 10001 (i.e. there are 10000 storms). This decline in storm severity might represent a climate change from wetter to drier conditions. Accordingly, the ratio of entrained sediment to water remains constant, i.e. the decrease in the mass of sediment entering the system with time is in proportion to the decrease in water. The fan generated by this simulation is rather similar to that created by simulation $\mathrm{B} 2$, but the main slopes are shallower and finer grained deposits are present at ground surface at the end of the simulation. Within the body of the fan, the coarsegrained deposits are more dominant reflecting the same conditions of early deposition as for case B2. The finegrained materials at the surface reflect the lower energies of the flood events at the later times. A continuous covering of fine-grained sediments is observed over the fan at the end of the simulation period.

\section{Discussion of the simulation results}

Of primary interest has been the assessment of the range of conditions that can be simulated using DSESS and the extent to which the results reflect known geological processes and observed sediment distributions. Each of the simulations demonstrates many of the expected geological characteristics described by Blair and McPherson (1994), Blum and Törnqvist (2000) and Clevis et al. (2003).

The sediment distributions developed in the model sediment profiles are consistent with typical characteristics of alluvial fans. For example, there is generally a lateral grading of sediments (Fig. 6), with local vertical reverse grading due to gravel front stepping (Fig. 7-B2 shows progressive upward stepping of some coarse units in the direction away from the fan apex). In addition, the simulations reproduce the characteristics of natural fan geometries: Fig. 7 shows, for example, radial concave upwards profiles, a plano-convex cross-profile, and radial symmetry (Blair and McPherson, 1994). Based on the thick sequences of coarse material seen in Fig. 7-B2, it also seems that some fan surface locations had persistently high flow rates associated with them. More commonly, though, a repeated cycle of scour, fill and avulsion is seen, with alternating aggradational and progradational events occurring at particular surface locations and recorded in the simulations as alternating fine/coarse grain size sequences.

Low intensity floods give rise to limited erosion and deposition, with consequently rather different flow geometries than observed for floods of higher magnitudes. Higher intensity floods and higher initial sediment loads yield greater erosion capacity but, once the sedimentcarrying capacity of the flood water is reached, the erosion rates reduce to zero and this can lead to different rates of land surface change with distance downstream of the source. The relationship between the sediment-carrying capacity and the flow geometry is found to be important and provides an illustration of the non-intuitive nature of the feedback mechanisms that can arise when using this type of model. Channelling of flows occurs on gentle slopes for flood waters with less entrained sediment, while fan deposition 
occurs for waters with higher sediment loads. For much steeper slopes, channelling is less likely as preferential directions for flow are not as distinct, though at high enough slopes or with great enough initial concentrations of entrained sediment, channelling can again be established. The development of conical fans at the inlet to the models and at the step change illustrates this point well.

Armouring could be a potentially significant control on the development of the landscape in dryland systems and deserves greater investigation as part of future modelling work with DSESS. The antecedent conditions play a strong role in determining the future geomorphological development of the land surface as suggested by Tooth (2000) and as illustrated by all the simulation results. The non-linear behaviour of the interacting processes and the stochastic components defining the pathways along which precipitons travel over the land mass are shown from the simulations to provide the possibility of generating a wide range of realisations that retain features observed in actual geological sequences.

\section{Summary and conclusions}

DSESS employs a process-based simulation approach (Crave and Davy, 2001) where discrete storm flood automata, discontinuous in time and space, are released to interact with a land surface and redistribute surface sediments through erosion, transportation and deposition. The modelling approach has been formulated to represent the hydraulic, geomorphological and climatic conditions of dryland systems (Blair and McPherson, 1994; Tooth, 2000). The sequence, not the timing, of dryland storm events is the critical aspect of dryland surface sediment redistribution, and the concept of a transport step in the model has been introduced to reflect this. DSESS employs previously developed empirical relationships for flow velocity and critical shear stress (Graf and Altinakar, 1998) and a recently-developed method for calculating sediment transport capacity (Abrahams et al., 2001) to calculate the exchange of sediments between the storm water and the underlying land surface. It is assumed that Hortonian flow is dominant (Lange et al., 1999; Tooth, 2000) and that the water table never reaches the land surface.

Tests on simple systems have been completed. These were designed to explore a range of physical settings that might be found within a dryland landscape. DSESS shows promise by being able to simulate plausible distributions of dryland flood-developed sediments over geological timescales without demanding excessive computer resources: the simulations presented here were run in 80 minutes or less using a BASIC code implementation of DSESS on a $1 \mathrm{GHz}$
PC with $256 \mathrm{Mb}$ of memory. The simulated grain size distributions developed in the model sediment profiles are consistent with typical dryland characteristics (Blair and McPherson, 1994): lateral grading, vertical reverse grading, radial concave upwards profiles and plano-convex crossprofiles, radial symmetry through scour channel filling and avulsion, gravel front stepping, coarse body confinement and alternation of aggradational and progradational events at particular surface locations. The results for the different tests illustrate the role of strong interactions between landscape topography, flood magnitude and grain size distribution in determining the pattern of erosion and deposition that will take place. The results are strongly nonlinear and different models yield strongly different results. A need now exists to constrain the model using a welldefined field data set.

DSESS is currently able to simulate only water-lain, sheetflood facies. However, previous work on dryland systems suggests the role played by mass wasting and debris flows in the supply of sediment to dryland surfaces, particularly in fan systems, is important (Blair and McPherson, 1994; Edwards et al., 1997). It is intended, next, to develop DSESS to account for debris flow conditions, i.e. when poorly sorted, fines-dominated sediments lying on steep slopes are catastrophically flooded (Blair and McPherson, 1994; Blair, 1999a; Franzi, 2002). The dryland environments in which alluvial fan sediments are formed are also host to aeolian processes which are especially important around the distal sand skirt. This represents another area for development.

Once the model has been extended and validated, the incorporation of diagenesis will be considered and ultimately, applied to groundwater solute transport studies.

\section{Acknowledgements}

The authors are grateful to Dr Sheila Peacock and Dr Ken Thomson for helping to bring data to life. Data visualisation was carried out using Surfer 7.00 by Golden Software, Inc., and Kingdom 7.2 VuPAK software by Seismic Microtechnology, Inc.

\section{References}

Abrahams, A. D., Li, G., Krishnan, C. and Atkinson J.F., 2001. A sediment transport equation for interrill overland flow on rough surfaces. Earth Surf. Process. Landf., 26, 1443-1459.

Allen, P. A. and Allen, J. R., 1990. Basin analysis: Principles and applications. Blackwell Science, London, UK.

Allen, D.J., Brewerton, L.J., Coleby, L.M., Gibbs, B.R., Lewis, M.A., MacDonald, A.M., Wagstaff, S.J. and Williams, A.T., 1997. The physical properties of major aquifers in England and Wales. BGS Technical Report WD/97/34. British Geological Survey, Keyworth, Nottingham, UK. 
Benton, M.J., Cook, E. and Turner, P., 2002. Permian and Triassic Red Beds and the Penarth Group of Great Britain. Joint Nature Conservation Committee, Peterborough, UK.

Blair, T.C., 1999a. Cause of dominance by sheetflood vs. debrisflow processes on two adjoining alluvial fans, Death Valley, California. Sedimentology, 46, 1015-1028.

Blair, T.C., 1999b. Sedimentary processes and facies of the waterlaid Anvil Spring Canyon alluvial fan, Death Valley, California. Sedimentology, 46, 913-940.

Blair, T.C., 1999c. Sedimentology of the debris-flow-dominate Warm Spring Canyon alluvial fan, Death Valley, California. Sedimentology, 46, 941-965.

Blair, T.C. and McPherson, J.G., 1994. Alluvial fans and their natural distinction from rivers based on morphology, hydraulic processes, sedimentary processes, and facies assemblages. $J$. Sediment. Res., A64, 450-489.

Blum, M.D. and Törnqvist, T.E., 2000. Fluvial responses to climate and sea-level change: a review and look forward. Sedimentology, 47(Suppl. 1), 2-48.

Bogardi, J.J., Duckstein, L. and Rumambo, O.H., 1988. Practical Generation of Synthetic Rainfall Event Time Series in a Semiarid Climate Zone. J. Hydrol., 103, 357-373.

Chopard, B. and Droz, M., 1998. Cellular automata modelling of physical systems. Cambridge University Press, Cambridge, UK.

Clevis, Q., de Boer, P. and Wachter, M., 2003. Numerical modelling of drainage basin evolution and three-dimensional alluvial fan stratigraphy. Sediment. Geol., 163, 85-110.

Collinson, J.D.,1996. Alluvial Sediments. In: Sedimentary Environments: Processes, Facies and Stratigraphy, H.G. Reading, (Ed.), Blackwell Science, Oxford, UK. 37-81.

Crave, A. and Davy, P., 2001. A stochastic 'precipiton' model for simulating erosion/sedimentation dynamics. Comput. Geosci., 27, 815-827.

D’Ambrosio, D., Di Gregorio, S., Iovine, G., Lupiano, V., Merenda, L., Rongo, R. and Spataro, W., 2002. Simulating the Curti-Sarno debris flow through cellular automata: the model SCIDDICA (release $\mathrm{S}_{2}$ ). Phys. Chem. Earth, 27, 1577-1585.

Davy, P. and Crave, A., 2000. Upscaling Local-Scale Transport Processes in Large-Scale Relief Dynamics. Phys. Chem. Earth, 25, 533-541.

Drago, M., 2002. A coupled debris flow-turbidity current model. Ocean Eng., 29, 1769-1780.

Edwards, R.A., Warrington, G., Scrivener, R.C., Jones, N.S., Haslam, H.W. and Ault, L., 1997. The Exeter Group, South Devon, England: A contribution to the early post-Variscan stratigraphy of northwest Europe. Geol. Mag., 134, 177-197.

Franzi, L., 2002. On the variability of the sediment concentration in currents on steep slopes: a simplified approach? Phys. Chem. Earth, 27, 1551-1555.

Graf, W.L., 1988. Fluvial Processes in Dryland Rivers. Springer, Berlin, Germany.

Graf, W.H. and Altinakar, M.S., 1998. Fluvial Hydraulics: Flow and transport processes in channels of simple geometry. Wiley, Chichester, UK.

Grove, A.T., 1977. The geography of semi-arid lands. Phil. Trans. Roy. Soc. London, B-278, 457-475.

Hardy, R.J., Bates, P.D. and Anderson, M.G., 2000. Modelling suspended sediment deposition on a fluvial floodplain using a two-dimensional dynamic finite element model. J. Hydrol., 229, 202-218.

Howard, A.D., Dietrich, W.E. and Seidl, M A., 1994. Modeling fluvial erosion on regional to continental scales. J. Geophys. Res., 99, 13971-13986.

Imran, J., Parker, G., Locat, J. and Lee, H., 2001. 1D numerical model of muddy subaqueous and subaerial debris flows. $J$. Hydraul. Eng., 127, 959-968.
Kelly, S.B. and Olsen, H., 1993. Terminal fans - a review with reference to Devonian examples. Sediment. Geol., 85, 339-374.

Knighton, A.D. and Nanson, G.C., 1997. Distinctiveness, diversity and uniqueness in arid zone river systems. In: Arid Zone Geomorphology: Process, Form and Change in Drylands, D.S.G. Thomas (Ed.), Wiley, Chichester, UK. 185-203.

Kocurek, G.A. 1996. Desert Aeolian Systems. In: Sedimentary Environments: Processes, Facies and Stratigraphy, H.G. Reading (Ed.), Blackwell Science, Oxford, UK.125-152.

Koltermann, C.E. and Gorelick, S.M., 1992. Palaeoclimatic Signature in Terrestrial Flood Deposits. Science, 256, 17751782.

Koltermann, C.E. and Gorelick, S.M., 1996. Heterogeneity in sedimentary deposits: A review of structure-imitating, processimitating, and descriptive approaches. Water Resour. Res., 32, $2617-2658$.

Laming, D.J.C., 1966. Imbrications, palaeocurrents and other sedimentary features in the Lower New Red Sandstone, Devonshire, England. J. Sediment. Petrol., 36, 940-959.

Lange, J.C., Leibundgut, C., Greenbaum, N. and Schick, A.P., 1999. A noncalibrated rainfall-runoff model for large, arid catchments. Water Resour. Res., 35, 2161-2172.

Milana, J.P. and Ruzycki, L., 1999. Alluvial-fan slope as a function of sediment transport efficiency. J. Sediment. Res., 69, 553562.

Paola, C., 2000. Quantitative models of sedimentary basin filling. Sedimentology, 47(Suppl.1), 121-178.

Reid, I. and Frostick, L.E., 1987. Flow Dynamics and Suspended Sediment Properties in Arid Zone Flash Floods. Hydrol. Process., 1, 239-253.

Ruffell, A. and Shelton, R., 1999. The control of sedimentary facies by climate during phases of crustal extension: examples from the Triassic of onshore and offshore England and Northern Ireland. J. Geol. Soc., 156, 779-789.

Salter, T., 1993. Fluvial scour and incision: models for their influence on the development of realistic reservoir geometries. In: Characterisation of Fluvial and Aeolian Reservoirs, C.P. North and D.J. Prosser (Eds.), Special Publication no. 73. Geol. Soc., London, 33-51.

Sclater, J.G. and Christie, P.A.F., 1980. Continental stretching: an explanation of post Mid-Cretaceous subsidence of the central North Sea basin. J. Geophys. Res., 85, 3711-3739.

Smith, T.R., Birnir, B. and Merchant, G.E., 1997a. Towards an elementary theory of drainage basin evolution: I. The theoretical basis. Comput. Geosci., 23, 811-822.

Smith, T. R., Merchant, G. E. and Birnir, B., 1997b. Towards and elementary theory of drainage basin evolution: II. A computational evaluation. Comput. Geosci., 23, 823-849.

Tetzlaff, D.M. and Harbaugh, J.W., 1989. Simulating Clastic Sedimentation. Van Nostrand Reinhold, New York, USA.

Tetzlaff, D.M. and Priddy, G., 2001. Sedimentary Process Modeling: From Academia to Industry. In: Geologic Modeling and Simulation, D.M.Merriam and J.C.Davis (Eds.), Kluwer, New York, USA. 1, 45-70.

Tooth, S., 1999. Floodouts in Central Australia. In: Varieties of Fluvial Form, A. Gupta, (Ed.), Wiley, Chichester, UK. 219247.

Tooth, S., 2000. Process, form and change in dryland rivers; a review of recent research. Earth-Sci. Rev., 51, 67-107.

Tucker, G.E. and Bras, R.L., 1998. Hillslope processes, drainage density, and landscape morphology. Water Resour. Res., 34, 2751-2764.

Tucker, G.E. and Slingerland, R., 1997. Drainage basin response to climate change. Water Resour. Res., 33, 2031-2047. 
Tucker, G.E., Lancaster, S.T., Gasparini, N.M. and Bras, R.L., 2001. The Channel-Hillslope Integrated Landscape Development Model (CHILD). In: Landscape Erosion and Evolution Modeling, R.S.Harmon and W.W.Doe III, (Eds.), Kluwer/Plenum, Dordredcht, the Netherlands. 349-388.

Veldkamp, A. and Tebbens, L.A., 2001. Registration of abrupt climate changes within fluvial systems: insights from numerical modelling experiments. Global Planet. Change, 28, 129-144.

Weast, R.C., 1981. Handbook of Chemistry and Physics. CRC Press, Boca Raton, Florida, USA.

Willgoose, G., Bras, R.L. and Rodrigueziturbe, I., 1991a. Results from a New Model of River Basin Evolution. Earth Surf. Process. Landf., 16, 237-254.
Willgoose, G., Bras, R.L. and Rodrigueziturbe, I., 1991b. A Coupled Channel Network Growth and Hillslope Evolution Model: 1. Theory. Water Resour. Res., 27, 1671-1684.

Willgoose, G., 1994. A statistic for testing the elevation characteristics of landscape simulation models. J. Geophys. Res., 99(B7), 13987-13996.

Wright, V.P., Marriott, S.B. and Vanstone, S.D., 1991. A 'reg' palaeosol from the Lower Triassic of south Devon: stratigraphic and palaeoclimatic implications. Geol. Mag., 128, 517-523. 